Article

\title{
Taxonomy of Means and Ends in Aquaculture Production-Part 4: The Mapping of Technical Solutions onto Multiple Treatment Functions
}

\author{
Bjorgvin Vilbergsson, Gudmundur V. Oddsson * and Runar Unnthorsson
}

Faculty of Industrial Engineering, Mechanical Engineering and Computer Science, Centre for Productivity, Performance and Processes, University of Iceland, Hjardarhagi 6107, Reykjavik IS-107, Iceland; bjoggivil@gmail.com (B.V.); runson@hi.is (R.U.)

* Correspondence: gvo@hi.is; Tel.: +354-5254635

Academic Editor: Kevin B. Strychar

Received: 15 June 2016; Accepted: 24 October 2016; Published: 4 November 2016

\begin{abstract}
Designing aquaculture production units will require decisions on which treatment to include, e.g., the intensification of the system, and then a decision on a technical solution for each treatment function selected to implement. To complicate matters, each technical solution is not unique to each treatment function, but has a multiple effect on the system. This interaction of a technical solution to multiple treatment functions will play a part in the decision making process. Previous work by the authors has made a taxonomy of all technical solutions for the treatment function, and in this article, how technical solutions affect treatment functions is mapped. The article views the aquaculture production system as a transformation process with three sets of functions, input, treatment and output. Based on a comprehensive literature review where all technical solutions were found and categorized into a taxonomy, their effect on treatment function was mapped using a quality function deployment (QFD). The result is a matrix that gives an evaluation on the interaction. This work is a step towards an aquaculture engineering design methodology.
\end{abstract}

Keywords: aquaculture production; transformation view; treatment function; taxonomy; technical solution

\section{Introduction}

Aquaculture production systems have been built for centuries, and the functions that are needed to grow fish are fairly well known. During the last few decades, fish production has been growing rapidly. Recent developments in recirculating aquaculture systems are focused on technical improvements of individual components and re-utilization of nutrients through the integration of fish and plants/algae [1]. Recirculating systems however are not perfect and have various problems. Many different solutions for recirculating systems exist; many have failed or are having difficulties that can often be traced back to the system design [2]. In order to effectively and efficiently design, implement and operate aquaculture systems, a general overview of available technical solutions and "how to integrate it all together" is required. According to Badiola et al. [2], this overview has never been made. This paper is the last in a series of four articles, which are all part of a study that is aimed at creating such an overview and take the first steps towards integrating it into a methodology. In the previous three papers, the authors identified all of the possible functions needed in a aquaculture production system. They also list the key variables that have to be monitored and collected all of the methods that solve the functions [3]. One part of the functions, the treatments, were then analyzed and all technical solutions to each method categorized into a taxonomy of technical solutions $[4,5]$. In this paper, the journey is concluded, and a map showing how each technical solution might solve multiple treatment functions is made. The result is presented in a quality function deployment form, 
like quality management deals with product design, i.e., a matrix of technical solutions and treatment functions is created and the link between those evaluated.

\section{Materials and Methods}

The methods used in this study are a comprehensive literature review and the quality function deployment from quality management. The scope, execution of the literature review and the synthesis is described in the next couple of sections.

\subsection{Literature Review}

This work is based on a literature review. Literature searches were carried out using The Web of Science ${ }^{\mathrm{TM}}$ online service. Two search sets (the keywords "aquacultur" and "RAS" vs. "aquacultur" and "reus") were selected to generate a platform to be further analyzed for technical solutions. Search 1 delivered 126 results, and Search 2 delivered 96 results. After the results were combined and the duplicates were deleted, a total count of 210 results, the articles were then analyzed in order to filter out those that did not discuss specific technical solutions to the relevant treatment function. The first filtering stage resulted in 116 articles. In the end, only 48 articles from the original search were used; a backward search resulted in 43 articles and books and specific searches resulted in 37 articles. Occasionally companies' websites were searched for more detailed descriptions of certain technical solutions.

\subsection{The Quality Function Deployment}

Quality function deployment (QFD) is derived from the Japanese phrase HinShitsu KiNo TenKai and can be translated to "method for allocating features, or method for translating characteristics" [6]. This is a simple approach used to describe the relationship between customer demand, product characteristics and manufacturing processes [6]. QFD can be used to grasp whole systems designs. Multiple matrices are linked together in a waterfall manner where each succeeding matrix goes further into the systems details.

In this work, QFD will be used to present how one solution can influence more than one treatment function. Performance indicators could then be plotted against the means in the next matrix in the QFD. To put this in better context with QFD, we can consider that the preceding matrices are as shown in Figure 1 in red.

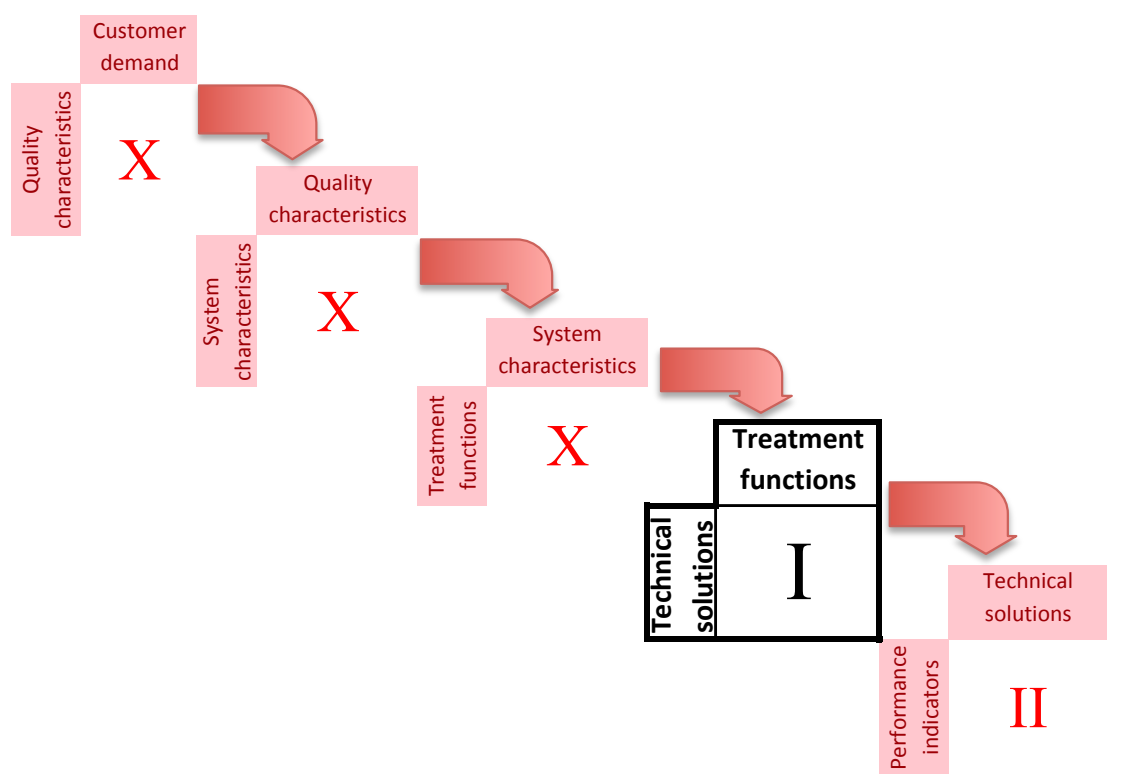

Figure 1. Quality function deployment (QFD) matrix setup. 
The notation used in the inner workings of QFD is at the discretion of the user. In this work, the authors have chosen to be general and only map out if there is an effect; the notation evaluates if it is a benefit or a negative effect. Three classifications are used to describe the relationship between the means and the treatment functions are hence: main function $(++)$, derived benefit $(+)$ and negative effect $(-)$. These relationships are taken from the results of the literature review.

Before presenting the results of the mapping of technical solutions to the treatment function, it is necessary to summarize the results of the literature review.

\section{The Taxonomy of Technical Solutions}

The following section is a summary of the authors previous articles [4,5]. The taxonomies of means (technical solutions $[4,5]$ ) are presented in each subsection along with a summary of how other treatment functions are or can be influenced.

The treatment functions are [3]: controlling temperature, solids, dissolved gasses (dissolved oxygen $\mathrm{DO}$ and $\mathrm{CO}_{2}$ ), $\mathrm{pH}$ (along with alkalinity and hardness), $\mathrm{N}$ compounds, organic matter, $\mathrm{P}$ compounds, metals, disease outbreak along with the function of preventing diseases. The treatment function of controlling disease outbreak is out of the scope.

\subsection{Controlling Solids}

Rapid removal of solids is a critical function in aquaculture systems. Solids mainly originate from feed and fish excrete. Particles can irritate fish gills, nourish fish pathogens [7], as well as consume dissolved oxygen and disrupt the function of other units in the system. Means used to control solids are presented in Figure 2.

Controlling solids

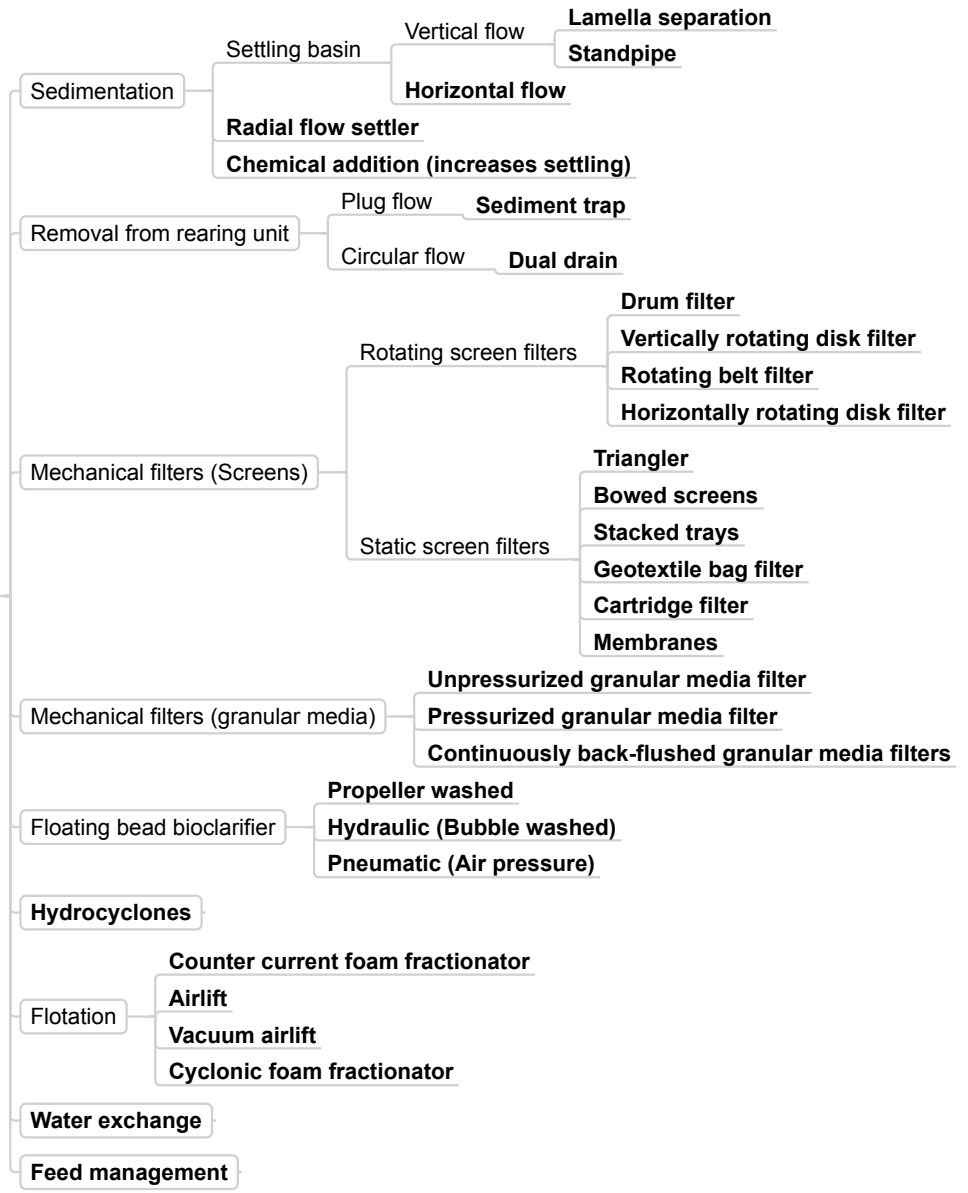

Figure 2. Taxonomy: controlling solids. 
Solids can be both inorganic and organic matter, split into settleable, suspended or fine (turbidity) solids. By removing solids, the biochemical oxygen demand (BOD) in the system is reduced along with $\mathrm{N}$ and $\mathrm{P}$ compounds [8]. Chemicals (polymers, alum or a combination of both) can be added to increase coagulation/flocculation of fine particles, increasing their size and settling speed [9], making them easier to remove. Membranes can reduce turbidity and potentially be used for advanced water treatment in recirculating aquaculture systems, i.e., microorganisms where extra high water quality is needed [10]. Bead filters offer both biofiltration and solid capture. Optimizing for both, however, can be difficult [11]. Flotation, also known as protein skimming or foam fraction, can be used to concentrate solids. Fine suspended solids and dissolved organic compounds can be removed by using the foam fraction ([12], p. 254).

\subsection{Controlling $\mathrm{pH}$, Alkalinity and Hardness}

Proper $\mathrm{pH}$ management is vital for the optimum performance of recirculating aquaculture systems [13]. Alkalinity is a measure of the buffering capacity of water, i.e., the water's capacity to neutralize strong acids, therefore keeping the $\mathrm{pH}$ constant [14]. Hardness expresses the concentration of metal ions in the water primarily calcium $\left(\mathrm{Ca}_{2}^{+}\right)$and magnesium $\left(\mathrm{Mg}_{2}^{+}\right)$, iron and manganese. The culture water needs to be relatively hard to support the development of fertilized fish eggs and calcification of larval skeletal structures [15]. Means used to control pH, alkalinity and hardness are presented in Figure 3.

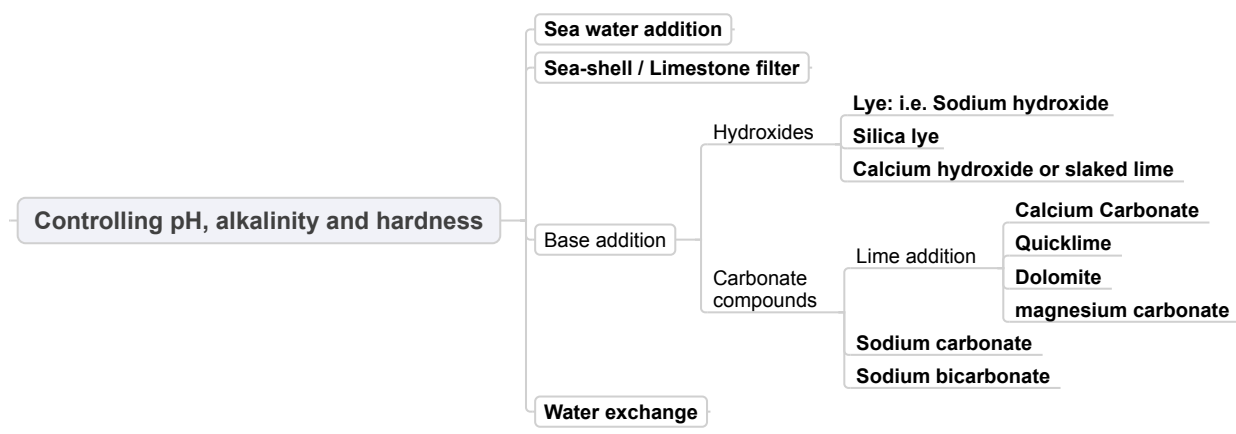

Figure 3. Taxonomy: controlling $\mathrm{pH}$, alkalinity and hardness.

In addition to being directly crucial to the growth and health of the cultured species, the $\mathrm{pH}$ also controls the ratio of un-ionized ammonia $\left(\mathrm{NH}_{3}\right)$ and ionized ammonia $\left(\mathrm{NH}_{4}^{+}\right)$formed. It also has a major effect on the performance of nitrifying bacteria in biofilters [13] and influences the toxicity of hydrogen sulfide and metals, such as copper, cadmium, zinc and aluminum [15]. $\mathrm{CO}_{2}$ production in aquaculture causes the $\mathrm{pH}$ in the system to lower.

Rosseland and Skogheim [16] demonstrated that adding seawater to the culture water $(1 \%-6 \%$ seawater) increased the $\mathrm{pH}$ and alkalinity of the water and decreased the labile aluminum. As water flows through the media bed of a shell-sand filter, the $\mathrm{pH}$ increases, and labile aluminum decreases [16]. Limestone can also be used as the medium.

In base addition, carbonate compounds increase the alkalinity of the water, i.e., the buffering capacity of the water. Lye can be used to increase the $\mathrm{pH}$, but does not increase the buffering capacity of the water [17]. Silica lye is a good alternative for increasing the $\mathrm{pH}$ when reducing the toxicity of aluminum is needed [18]. Applying calcium hydroxide at around $10 \%-20 \%$ of the daily feed increases the $\mathrm{pH}$ and alkalinity in aquaculture systems [19]. Calcium hydroxide can also be used as a flocculant [20]. Limestone, which is most often a mixture of calcium carbonate and magnesium carbonate or dolomite, is a major source of alkalinity and hardness [21]. In ozonized systems, calcium carbonate has no effect on increasing alkalinity [22]. The dissolution of limestone is dependent on the dissolved $\mathrm{CO}_{2}$ concentration [21]. Quicklime can be used to reduce the toxicity of copper [23] and cadmium [24] to fish. Using lime slurry, however, increase the particle content (turbidity) of the 
water [17]. Sodium carbonate and sodium bicarbonate can be used to increase the $\mathrm{pH}$ and alkalinity of water [13,15]. By adding calcium and magnesium, the water is hardened, and also, the toxicity of dissolved metals is decreased [15].

\subsection{Controlling $\mathrm{DO}$ and $\mathrm{CO}_{2}$}

Maintaining the right levels of dissolved gasses, such as dissolved oxygen and carbon dioxide, is vital to the health of the cultured species and the operation of certain processes [25]. As oxygen is consumed by the cultured species or other organisms in the system, for the metabolic process, the $\mathrm{CO}_{2}$ concentrations increases. Other organisms are for instance nitrifying and heterotrophic bacteria. The means used to control $\mathrm{DO}$ and $\mathrm{CO}_{2}$ are presented in Figure 4.

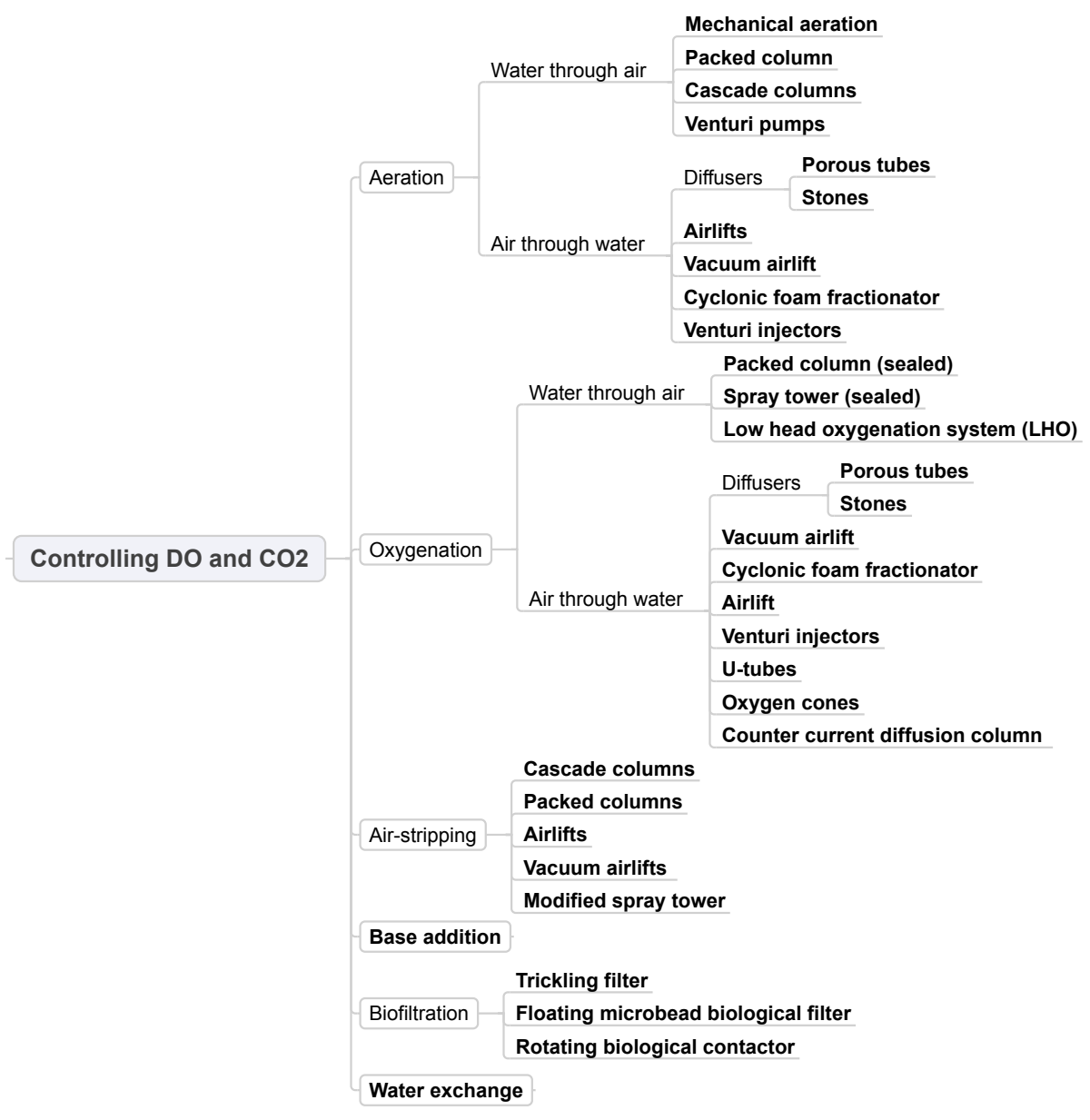

Figure 4. Taxonomy: controlling $\mathrm{DO}$ and $\mathrm{CO}_{2}$.

In solution where water comes in contact with air, some gas exchange will take place. A packed column aerators can be used for both oxygen transfer and nitrogen removal [26]. Modifications of the spray tower have been tested to provide concurrent $\mathrm{CO}_{2}$ stripping [27].

Airlifts, which were briefly mentioned earlier, can be used for aeration and degasification along with their water delivery [28]. Barrut et al. [29] found that vacuum airlifts could be a promising method for $\mathrm{CO}_{2}$ stripping. Other airlifts could also provide air stripping $[28,30]$.

Another way of controlling $\mathrm{CO}_{2}$ is using base addition to regulate $\mathrm{pH}$ : increasing the $\mathrm{pH}$ decreases the $\mathrm{CO}_{2}$. These bases are either carbon-containing (such as sodium bicarbonate) or not (such as sodium hydroxide). Carbon-containing bases also increase the total carbonate carbon in the system [31]. However, this requires careful monitoring and needs to be in conjunction with the management of the $\mathrm{pH}$ and alkalinity in the system. 
The main purpose of biofilters is to remove ammonia from the process water in recirculating aquaculture systems. Some types of biofilters also provide aeration and some $\mathrm{CO}_{2}$ stripping. Trickling filters can aerate the water and provide some $\mathrm{CO}_{2}$ stripping [31,32]. Floating microbead biological filters can provide $\mathrm{CO}_{2}$ stripping. If a gas space between the top of the beads and the water spray is created, stripping can be forced [33]. Brazil [34] found that rotating biological contactors removed an average $39 \%$ of carbon dioxide.

\subsection{Controlling N Compounds}

Nitrogen is a nutrient essential to all living organisms. Main sources of nitrogen in aquaculture are metabolic waste from fish and uneaten or undigested feed [35]. Fish also discharges various nitrogenous waste products that decompose into toxic compounds, such as ammonia and nitrite. These compounds are toxic to fish and, therefore, of great interest in intensive recirculating aquaculture systems [12]. Figure 5 displays the taxonomy of means for the treatment function controlling $\mathrm{N}$ compounds.

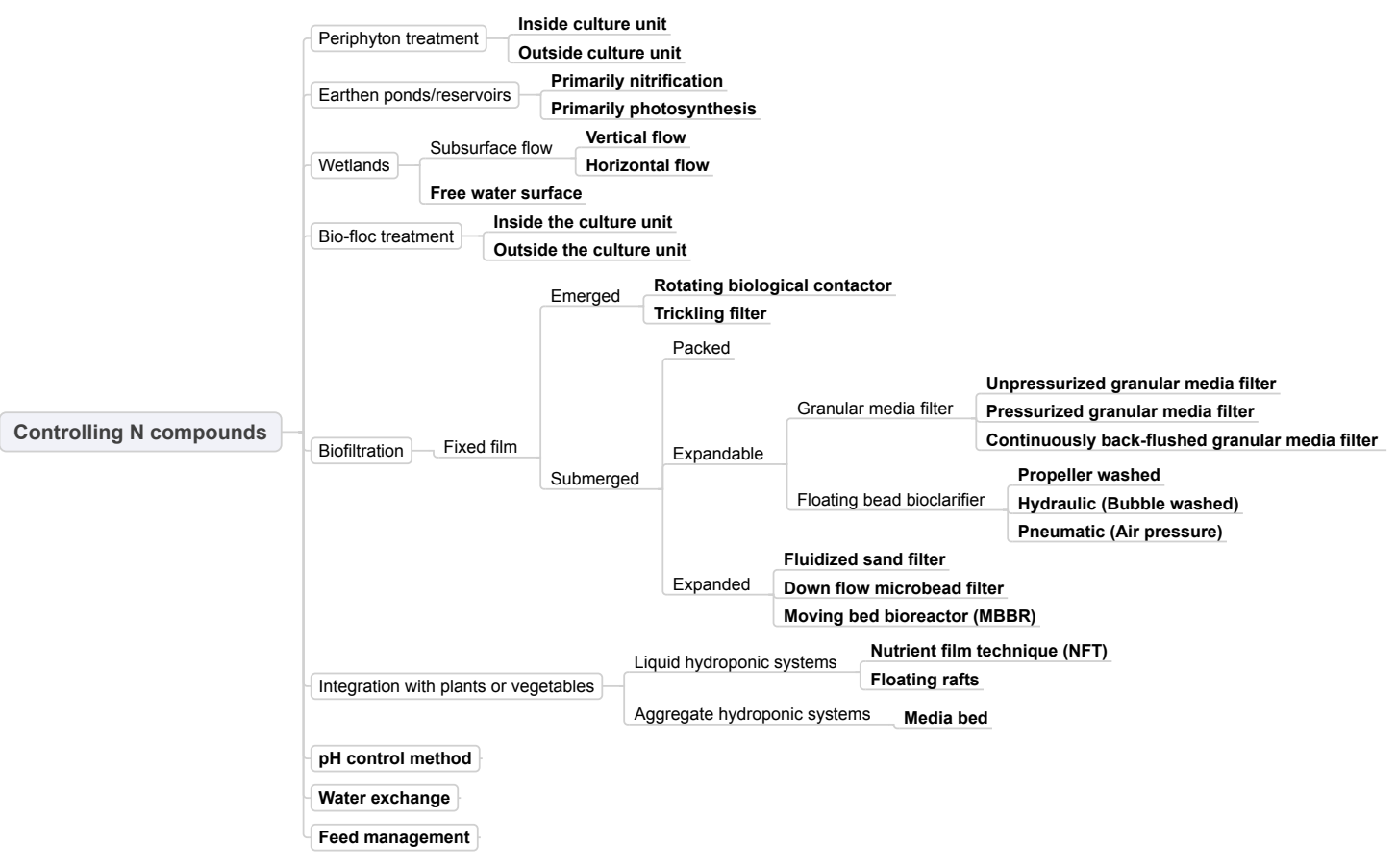

Figure 5. Taxonomy: controlling $\mathrm{N}$ compounds.

In nitrification processes, ammonia and nitrite are oxidized to less toxic nitrate [12]. To prevent the accumulation of nitrate in the system, water exchange or a denitrification process is needed [36]. Nitrification is an aerobic process, therefore consuming oxygen, while denitrification is an anaerobic process converting nitrate into nitrogen gas [12]. The nitrification process produces $\mathrm{H}+$, consuming alkalinity, which needs to be compensated with base addition to prevent lowering of the $\mathrm{pH}[13,37]$ and accounts for a large production of $\mathrm{CO}_{2}$ in the system [38].

When using periphyton treatment, organisms trap and process suspended organic matter and utilize nutrients in the water via photosynthesis. It therefore produces $\mathrm{O}_{2}$, removes $\mathrm{CO}_{2}$ and potentially provides extra food for the cultured species [39], which helps to manage the $\mathrm{pH}$ [35].

Bio-flocs take up particulate organic matter and nitrogen waste from the fish, decreasing ammonium concentrations within the system and creating a supplementary protein source for the fish $[35,40]$. A bio-floc system is designed to use little or no water exchange. This causes nutrients that cannot be lost atmospherically, such as phosphorus and phosphate, to accumulate in the system [41]. Phosphorus that is retained within particulate matter flocculates and can be eaten by the cultured 
species. The bio-floc process is aerobic, therefore lowering the dissolved oxygen content of the water. The consumption of alkalinity by heterotrophic and nitrifying bacteria present in bio-floc causes a reduction in alkalinity and $\mathrm{pH}$ in the system [19].

In earthen ponds, $\mathrm{N}$ removal is primarily done either by nitrification or photosynthesis (phytoplankton uptake). Phytoplankton, such as algae, can be used as a supplement feed source for animal cultures [42]. Algae retains phosphorus [42], and sediment in ponds can have good $\mathrm{P}$ absorption capacity [43].

Constructed wetlands can be used for water treatment in recirculation systems to reduce total suspended solids (TSS), TANand P [44]. Plants of various types serve, among other organisms, the purpose of removing nutrients ( $\mathrm{N}$ and $\mathrm{P}$ ) from the processing water for reuse [45]. This is done via nitrification and plant uptake [45]. Occurring microorganisms in constructed wetlands can inactivate pathogenic microorganisms in the system, given an adequate retention time [17].

In a rotating biological contactor (RBC), several stages can be used. By recycling part of the process water from the last stage to the first, studies show improvements in $\mathrm{COD}, \mathrm{BOD}_{5}$, ammonia removal and an increase of DO concentrations [46] along with denitrification of the recirculation water [47]. As the media contacts air, $\mathrm{CO}_{2}$ is stripped from the water, and oxygen is supplemented [34]. With controlled ventilation (the ratio of air to water flow needs to be around 10), trickling filters can also provide degassing or $\mathrm{CO}_{2}$ stripping and even evaporation cooling in warm climates [48]. Floating bead bioclarifiers (bead filters) provide nitrification in addition to solid removal and, if operated in anaerobic conditions, denitrification [49]. A fluidized sand filter can also be used for heterotrophic denitrification [50]. By allowing space between the media and the water spray, in downflow microbead filters, gas stripping can be forced [33]. Air blower and ventilation then needs to be installed. Moving bed bioreactor (MBBR) can be either operated as an aerobic process (nitrification) or anoxic and anaerobic processes [51].

Hydroponics strip the process water of nutrients, such as nitrates and phosphorus. Lennard and Leonard [52], comparing NFT, floating rafts and media beds, found DO of the process water to decrease over all three types of hydroponic beds. In media bed systems, plant roots and media can provide a surface area for nitrifying bacteria and solid capture $[52,53]$.

\subsection{Controlling Organic Matter}

Organic matter consists of impurities in the culture water that originate from feeding and metabolic waste. Organic matter can be split into solid and dissolved organic matter. The partial taxonomy of means is presented in Figure 6. Solid organic matter can be removed using the solid removal techniques (see Section 3.1). Some methods such as flotation with ozone are very effective in removing particulate organic matter [54].

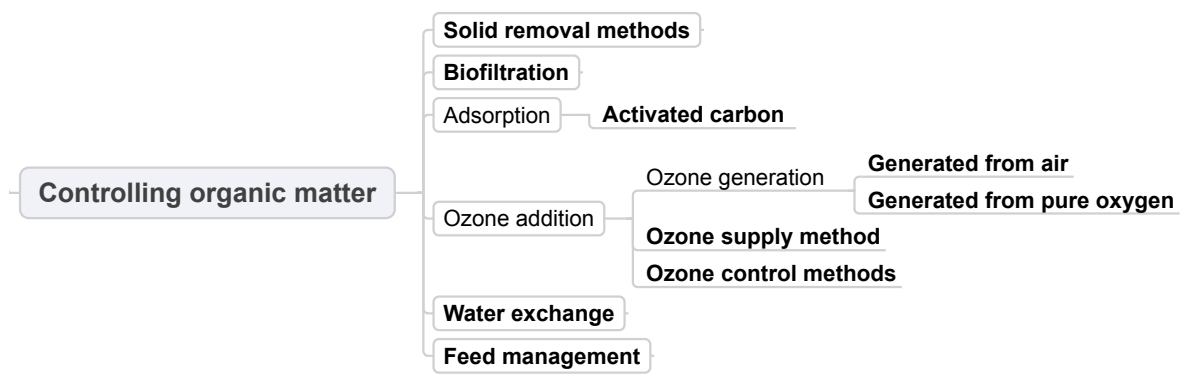

Figure 6. Taxonomy: controlling organic matter.

Several means can be used to remove dissolved organic matter. In biofilters, dissolved organic matter can be oxidized, therefore reducing its concentration [55]. Hydroponic beds can remove dissolved organic matter in recirculating aquaponic systems [56], and adsorption onto activated carbon can be used for the removal of dissolved organic carbon along with therapeutants [57]. 
Ozone can improve multiple water quality indicators, including oxidizing toxic nitrite to nitrate [58], removal of organic compounds by oxidizing dissolved organic matter and improving flocculation of fine and colloidal particulates; that results in better particle removal via settling, filtration [59] or foam fractionation [58].

\subsection{Controlling P Compounds}

In aquaculture phosphorus $(\mathrm{P})$ enters the culture unit with feed. Not all $\mathrm{P}$ provided is utilized by the cultured species, and part of it is retained in the system either as uneaten feed or excretes. Disintegration and bacterial degradation of solids, temperature and incubation time, all influence the amount of phosphorus which is lost from the solid form to dissolved by bacterial degradation and leaching [60]. As solid phosphorus stays longer in the system, goes though equipment, etc., more gets dissolved into the culture water, making it more difficult to remove. The partial taxonomy is presented in Figure 7.

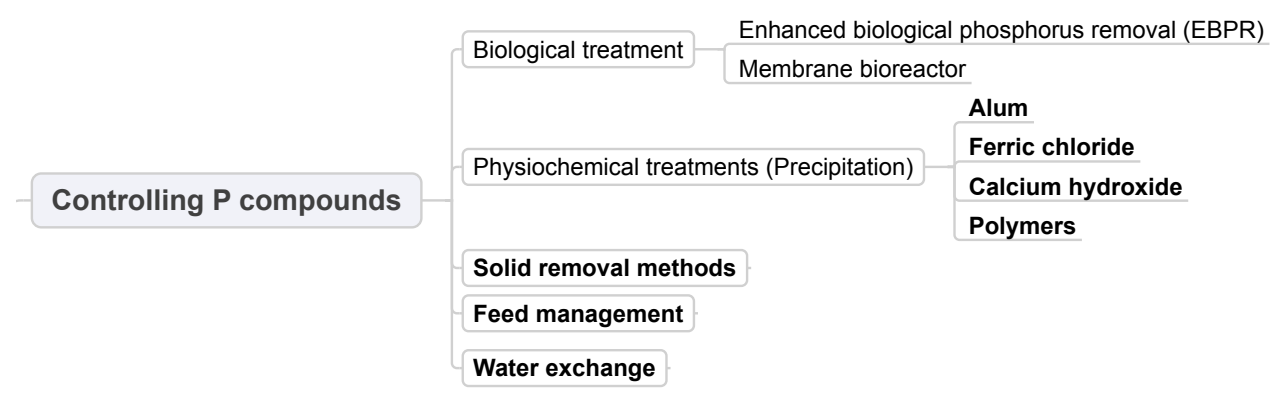

Figure 7. Taxonomy: controlling P compounds.

In physicochemical treatment, chemicals are added to increase the coagulation/flocculation of dissolved phosphorus. Chemicals, such as alum, ferric chloride and calcium hydroxide, can be used to coagulate dissolved phosphorus [20]. Polymers can also be used, but are not as effective at removing phosphorus [9]. However, using polymers in conjunction with other chemicals, such as alum [9] or calcium hydroxide [20], shows much better results.

\subsection{Controlling Metals}

Metal compounds can become toxic to the cultured species, the environment or the consumer. This includes both heavy metals (cadmium, copper, etc.) and other metals (aluminum, iron, etc.). Metals can originate from the corrosion of pipes and fittings or from feed [25]. The partial taxonomy is presented in Figure 8.

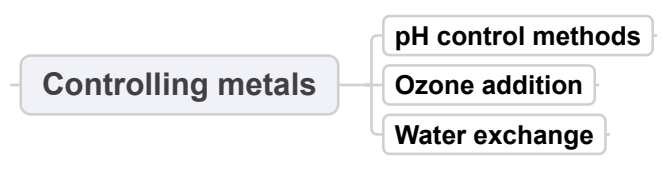

Figure 8. Taxonomy: controlling metals.

By increasing the alkalinity and hardness of the culture water, the toxicity of metals, such as copper, cadmium and zinc, can be reduced [25]. Shell-sand filter and seawater addition can lower the labile (inorganic) aluminum in the culture water [16]; silica lye can also be used to decrease the toxicity of aluminum [17]; and calcium and magnesium decrease the toxicity of dissolved metals [15].

Ozone addition can be used to "significantly" lower dissolved copper and iron in systems with a low water exchange rate, such as RAS. The concentration of dissolved zinc can be lowered, as well [37]. 


\subsection{Preventing Diseases}

Over 100 fish diseases exist and are caused by various microorganisms, such as bacteria, viruses, fungi and parasites. Diseases are mainly introduced to the system through the water, the fish or the equipment used, such as nets, baskets, gloves, etc. [61]. The means used to prevent diseases are presented in the partial taxonomy in Figure 9.

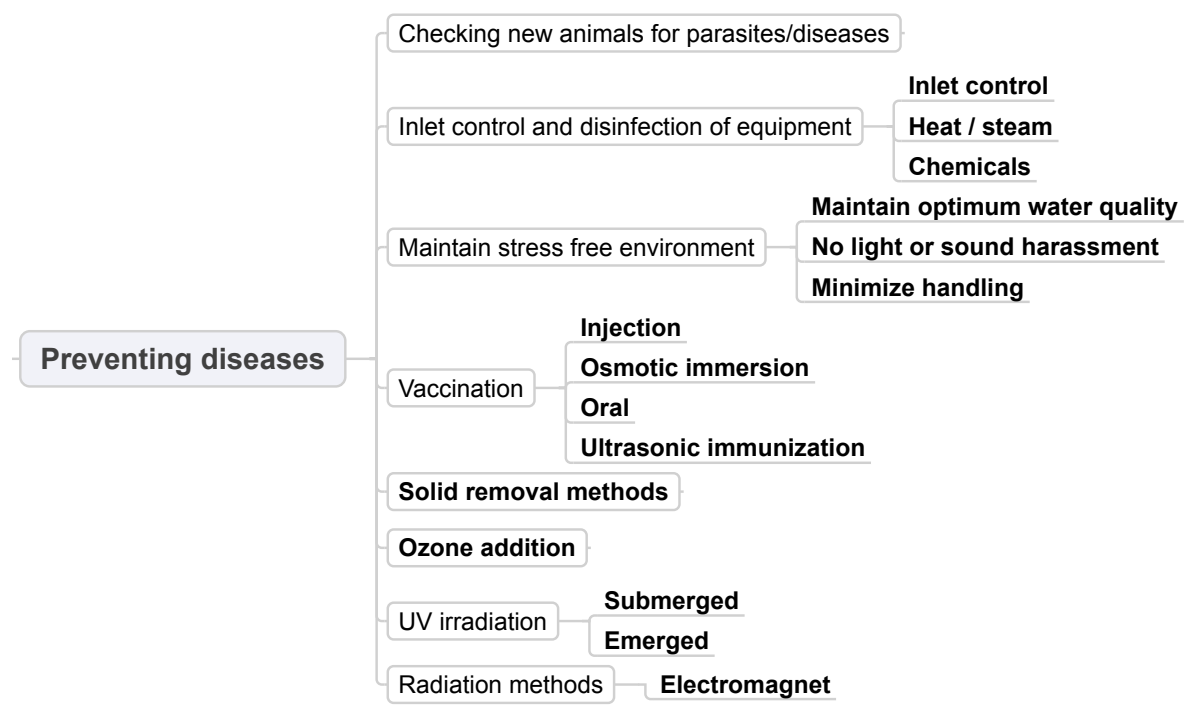

Figure 9. Taxonomy: preventing diseases.

Adding ozone at a lower rate just before entering the culture tanks could lower the risk of bacteria gill disease and the number of heterotrophic bacteria [62].

Using UV as the main disinfectant process has increased in popularity for aquaculture water, as it is very effective for inactivating the pathogens Cryptosporidium and Giardia lamblia without forming any byproducts [63]. Treating the culture water with ozone followed by UV irradiation can result in "practically complete disinfection" of total heterotrophic bacteria count [64]. The UV irradiation then both acts as a disinfectant, as well as destroying remaining ozone.

Disinfection of all equipment before use in the system or when moving equipment between tanks will reduce the likelihood of diseases spreading [61].

Many microorganisms are attached to solids, so removing them from the system with the previously-mentioned solid removal methods will decrease the total number of microorganisms within the system. With a small enough mesh size $(<20 \mathrm{um})$, some organisms can be filtered out, while membranes $(<1 \mathrm{~nm})$ can remove all types of microorganisms [17].

Exposing fish (rainbow trout) to specific low frequency electromagnetic fields has "possible effects on growth performance, non-specific immunity and disease resistance" [65]. Stressed fish is more susceptible to diseases [61]. Water quality has a large influence on fish stress. However, stress can be produced by other factors, such as light or sound [61].

Vaccines can protect aquatic animals against some viral and bacterial diseases. The effect is however dependent on the aquaculture species and diseases [66].

\subsection{Controlling Temperature}

The temperature of the culture water is important. Each species has its temperature tolerance and range for optimum survival and growth. If the culture water temperature needs to be much higher than the inlet water temperature, lower water exchange rates could save heating costs. The partial taxonomy is presented in Figure 10. 


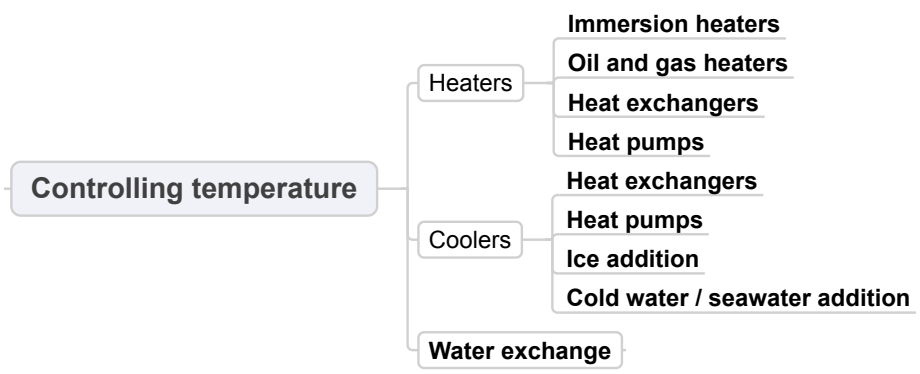

Figure 10. Taxonomy: controlling temperature.

The technical solutions and the treatment functions are now introduced, and in the rest of this article, we will present the result of the interaction in a matrix format.

\section{The Quality Function Deployment Matrix of Technical Solutions and Treatment Functions}

The quality function deployment is a well-known tool to use in product development. It allows a visual overview of many aspects of the product, and it helps designers to discuss the pros and cons of different possible solutions. Often, the QFD process is done in a cascading manner to link customers to the actual product attributes. Here, we only propose one matrix of the interaction between treatment functions and technical solutions. The other matrices, both in front and behind (see Figure 1), are fine targets for future work.

\section{Means vs. Treatment Functions}

Technical solutions (means) often influence more than one treatment function. The QFD matrix presented here was developed to describe the relationship between a specific technical solution and all treatment functions. Technical solutions with a similar effect were grouped together for easier reading of the matrix (see Table 1).

Table 1. Grouping of Technical solutions with a similar effect for easier reading of the matrix presented in Tables 2 to 8 .

\begin{tabular}{|c|c|}
\hline Group & Technical solutions \\
\hline Settleable particle removal & $\begin{array}{l}\text { Sediment trap in plug flow raceway } \\
\text { Dual drain } \\
\text { Horizontal flow settling basin } \\
\text { Standpipe } \\
\text { Lamella separation } \\
\text { Radial flow settler } \\
\text { Hydrocyclones }\end{array}$ \\
\hline Screen filters & $\begin{array}{l}\text { Drum filter } \\
\text { Vertically rotating disk filter } \\
\text { Rotating belt filter } \\
\text { Horizontally rotating disk filter } \\
\text { Triangler } \\
\text { Bowed screens } \\
\text { Stacked trays } \\
\text { Geotextile bag filter }\end{array}$ \\
\hline Granular media filter & $\begin{array}{l}\text { Unpressurized granular media filter } \\
\text { Pressurized granular media filter } \\
\text { Continuously back-flushed gr. m. filter }\end{array}$ \\
\hline Diffusers & \begin{tabular}{|l} 
Diffusers - porous tubes \\
Diffusers - porous stones
\end{tabular} \\
\hline Periphyton treatment & $\begin{array}{l}\text { Periphyton treatment inside culture unit } \\
\text { Periphyton treatment outside culture unit }\end{array}$ \\
\hline Bio-floc treatment & $\begin{array}{l}\text { Bio-floc treatment inside culture unit } \\
\text { Bio-floc treatment outside culture unit }\end{array}$ \\
\hline Wetlands & $\begin{array}{l}\text { Subsurface wetlands } \\
\text { Free water surface wetlands }\end{array}$ \\
\hline Bead filters & $\begin{array}{l}\text { Propeller washed bead filter } \\
\text { Hydraulically washed bead filter } \\
\text { Pneumatically wahed bead filter }\end{array}$ \\
\hline Floating raft and NFT aquaponic systems & $\begin{array}{l}\text { NFT aquaponic system } \\
\text { Floating raft aquaponic systems }\end{array}$ \\
\hline
\end{tabular}


In matrix I, separated into Table 2 through Table 8 (the full matrix is available in a Supplementary Materials), the treatment functions are on the $y$-axis divided into sub-functions. The means are listed up on the $x$-axis roughly in the order they appear in this article. Three classifications are used to describe the relationship between the means and the treatment functions; main function $(++)$, derived benefit $(+)$ and negative effect $(-)$. For example, solid removal techniques have the main function $(++)$ of removing solids. By removing solids, they will not be degraded in the system and cause reduction in $\mathrm{DO}$ and increased $\mathrm{CO}_{2}(+)$. Further, solids can contain $7 \%-32 \%$ of the total nitrogen and $30 \%-84 \%$ of the total phosphorus in the system [11]. Finally, microorganisms that are attached to solids are removed, lowering the chances of any diseases $(+)$. Foam fraction techniques used for fine solid removal and dissolved organic compounds $(++)$ also provide aeration at the same time $(+)$. The foam fraction with ozone injection organic matter removal becomes much more efficient $(++)$. Membranes' main purpose is to remove impurities $(++)$. However, with a small enough mesh size $(<1 \mathrm{~nm})$, they can be used to remove microorganisms, as well $(++)$ [17]. With proper feed management, waste production can be reduced, resulting in less organic $(++)$ and inorganic $(++)$ solids; BOD is reduced $(+)$, as well as nitrogen and phosphorus loading $(++)$. Water exchange is used, in relation to other means, to control all treatment functions (++). This part of the matrix is presented in Table 2.

Table 2. QFD matrix presenting how feed management, water exchange and solid removal techniques influence different treatment functions.

\begin{tabular}{|c|c|c|c|c|c|c|c|c|c|c|c|c|c|c|c|c|c|c|c|c|c|c|c|c|}
\hline \multirow{2}{*}{$\begin{array}{l}\text { Abbreviations: } \\
\text { DO: dissolved oxygen, N: nitrogen, } \\
\text { OM: organic matter, P: phosphorus, } \\
\text { Prev: preventing, comp: compound } \\
\qquad \text { Technical solutions }\end{array}$} & \multirow{2}{*}{ 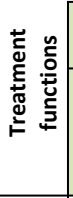 } & \multicolumn{3}{|c|}{ Ctrl. solids } & \multicolumn{3}{|c|}{ Ctrl. pH } & \multicolumn{2}{|c|}{$\begin{array}{c}\text { Ctrl. DO } \\
\& \mathrm{CO}_{2} \\
\end{array}$} & \multicolumn{3}{|c|}{$\begin{array}{l}\text { Ctrl. N } \\
\text { comp }\end{array}$} & \multicolumn{2}{|c|}{$\begin{array}{l}\text { Ctrl. } \\
\text { OM }\end{array}$} & \multicolumn{2}{|c|}{$\begin{array}{l}\text { Ctrl. P } \\
\text { comp } \\
\end{array}$} & \multicolumn{5}{|c|}{ Ctrl. metals } & \multirow[b]{2}{*}{ 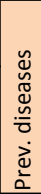 } & \multicolumn{2}{|c|}{$\begin{array}{l}\text { Ctrl. } \\
\text { temp }\end{array}$} \\
\hline & & 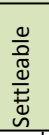 & 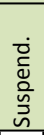 & $\underset{i=}{c}$ & 퐁 & $\begin{array}{l}\frac{2}{\sqrt{5}} \\
\frac{.0}{\pi} \\
\frac{1}{4} \\
\end{array}$ & 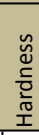 & 음 & ర్ర & 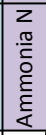 & 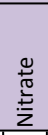 & 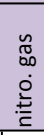 & $\begin{array}{l}\text { 음 } \\
\text { n } \\
\end{array}$ & $\begin{array}{l}\bar{d} \\
\geq \\
\bar{d} \\
\stackrel{y}{0} \\
\vdots \\
\end{array}$ & 음 & 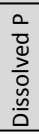 & 으 & $\begin{array}{l}\frac{\varepsilon}{J} \\
. \frac{\partial}{\varepsilon} \\
\frac{\xi}{J} \\
\end{array}$ & $\stackrel{\text { I }}{\stackrel{N}{N}}$ & 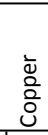 & $\frac{\xi}{\partial}$ & & 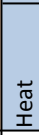 & ¿̊. \\
\hline Feed management & & ++ & ++ & ++ & & & & + & + & ++ & & & ++ & ++ & ++ & & & & & & & + & & \\
\hline Water exchange & & ++ & ++ & ++ & ++ & ++ & ++ & ++ & ++ & ++ & ++ & ++ & ++ & ++ & ++ & ++ & ++ & ++ & ++ & ++ & ++ & + & ++ & ++ \\
\hline Settleable particle removal & & ++ & & & & & & + & + & + & & & ++ & & + & & & & & & & + & & \\
\hline Screen filters & & & +++ & & & & & + & + & + & & & ++ & & + & & & & & & & + & & \\
\hline Cartridge filter & & & ++ & ++ & & & & + & + & + & & & ++ & & + & & & & & & & + & & \\
\hline Membrane & & & ++ & ++ & & & & + & + & + & & & ++ & & + & & & & & & & ++ & & \\
\hline Granular media filters & & & ++ & & - & & & + & + & ++ & & & ++ & & + & & & & & & & + & & \\
\hline Vacuum airlift fractionator & & & ++ & ++ & + & & & + & + & + & & + & ++ & ++ & & & & & & & & + & & \\
\hline Cyclonic foam fractionator & & & ++ & ++ & & & & + & + & + & & + & ++ & ++ & & & & & & & & + & & \\
\hline Airlift fractionator & & & ++ & ++ & & & & + & + & + & & + & ++ & ++ & & & & & & & & + & & \\
\hline
\end{tabular}

In Table 3, means to control the $\mathrm{pH}$ are presented. Managing the $\mathrm{pH}$ of the culture water is vital since the $\mathrm{pH}$ has a major effect on the performance of nitrifying bacteria $(+)$ and controls the ratio of un-ionized ammonia $\left(\mathrm{NH}_{3}\right)$ and ionized ammonia $\left(\mathrm{NH}_{4}^{+}\right)$formed $(+)$. By increasing the $\mathrm{pH}$ and alkalinity, the toxicity of metals (zinc, copper, cadmium) is reduced $(+)$. Seawater addition can be used to increase the $\mathrm{pH}(++)$ and alkalinity $(++)$ of the culture water. Labile aluminum is also reduced with seawater addition $(+)$.

Sea-shell/limestone filters can be used to increase the $\mathrm{pH}(++)$, alkalinity $(++)$ and hardness $(++)$ of the culture water. $\mathrm{CO}_{2}$ is used in the reaction process with the sea-shell/limestone and is therefore decreased (+). Using Lye and silica lye increases the $\mathrm{pH}(++)$, but not the alkalinity (i.e., buffering capacity). However, silica lye can be used to decrease the toxicity of aluminum $(++)$. Calcium hydroxide increases the $\mathrm{pH}(++)$ and alkalinity $(++)$ along with its precipitation abilities $(++)$. Lime (calcium carbonate, quicklime, dolomite and magnesium carbonate) can be used to control the $\mathrm{pH}(++)$, alkalinity $(++)$ and hardness $(++)$ of the water. Quicklime has been proven to specifically reduce the toxicity of copper and cadmium $(++)$. Sodium carbonate and sodium bicarbonate (baking soda) can be used to increase the $\mathrm{pH}(++)$ and alkalinity $(++)$ of the water. By adding calcium and magnesium into the water, the hardness is increased $(++)$. 
Table 3. QFD matrix presenting how $\mathrm{pH}$ control methods influence different treatment functions.

\begin{tabular}{|c|c|c|c|c|c|c|c|c|c|c|c|c|c|c|c|c|c|c|c|c|c|c|c|}
\hline \multirow{2}{*}{\begin{tabular}{l} 
Abbreviations: \\
DO: dissolved oxygen, N: nitrogen, \\
OM: organic matter, P: phosphorus, \\
Prev: preventing, comp: compound \\
\multicolumn{1}{c}{ Technical solutions }
\end{tabular}} & \multicolumn{3}{|c|}{ Ctrl. solids } & \multicolumn{3}{|c|}{ Ctrl. pH } & \multicolumn{2}{|c|}{$\begin{array}{l}\text { Ctrl. DO } \\
\& \mathrm{CO}_{2}\end{array}$} & \multicolumn{3}{|c|}{$\begin{array}{l}\text { Ctrl. N } \\
\text { comp }\end{array}$} & \multicolumn{2}{|l|}{$\begin{array}{l}\text { Ctrl. } \\
\text { OM }\end{array}$} & \multicolumn{2}{|c|}{$\begin{array}{l}\text { Ctrl. P } \\
\text { comp }\end{array}$} & \multicolumn{5}{|c|}{ Ctrl. metals } & \multirow{2}{*}{ 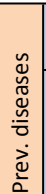 } & \multicolumn{2}{|c|}{$\begin{array}{l}\text { Ctrl. } \\
\text { temp }\end{array}$} \\
\hline & 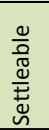 & $\begin{array}{l}\dot{0} \\
\stackrel{0}{\nu} \\
\frac{0}{n} \\
\tilde{n}\end{array}$ & 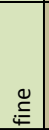 & $\frac{1}{2}$ & 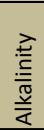 & 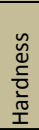 & 음 & రิ & \begin{tabular}{|l|}
$z$ \\
.$\frac{\pi}{\tau}$ \\
$\delta$ \\
$\xi$ \\
$\xi$ \\
$\xi$ \\
\end{tabular} & 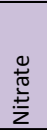 & 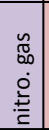 & 음 & 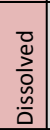 & 믐 & 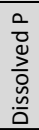 & 오 & 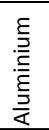 & $\underset{\sim}{\stackrel{U}{N}}$ & $\begin{array}{l}\overline{0} \\
\stackrel{0}{0} \\
\dot{0}\end{array}$ & $\begin{array}{l}\frac{E}{\underline{E}} \\
\frac{E}{0} \\
\widetilde{U} \\
\end{array}$ & & $\begin{array}{l} \\
\stackrel{0}{\pi} \\
\frac{\mathbb{1}}{I}\end{array}$ & $\overline{8}$ \\
\hline Seawater addition & & & & ++ & ++ & & & & + & & & & & & & & + & + & + & + & & & \\
\hline Sea-shell / limestone filter & & & & ++ & ++ & ++ & & + & + & & & & & & & & + & + & + & + & & & \\
\hline Lye (sodium hydroxide) $(\mathrm{NaOH})$ & & & & ++ & & & & + & + & & & & & & & & & + & + & + & & & \\
\hline Silica lye & & & & ++ & & & & + & + & & & & & & & & ++ & + & + & + & & & \\
\hline Calcium hydroxide or slaked lime $(\mathrm{Ca}(\mathrm{OH}) 2)$ & + & ++ & ++ & ++ & ++ & & & + & + & & & ++ & & ++ & ++ & & & + & + & + & & & \\
\hline Calcium Carbonate (CaCO3) & & & & ++ & ++ & ++ & & + & + & & & & & & & & & + & + & + & & & \\
\hline Quicklime (CaO) & & & & ++ & ++ & ++ & & + & + & & & & & & & & & + & ++ & ++ & & & \\
\hline Dolomite $((\mathrm{CaMg}(\mathrm{CO} 3)) 2$ & & & & ++ & ++ & ++ & & + & + & & & & & & & & & + & + & + & & & \\
\hline Magnesium carbonate (MgCO3) & & & & ++ & ++ & ++ & & + & + & & & & & & & & & + & + & + & & & \\
\hline Sodium carbonate (Na2CO3) & & & & ++ & ++ & & & + & + & & & & & & & & & + & + & + & & & \\
\hline Sodium bicarbonate (NaHCO3) & & & & ++ & ++ & & & + & + & & & & & & & & & + & + & + & & & \\
\hline
\end{tabular}

In Table 4, means specifically intended for $\mathrm{DO}$ and $\mathrm{CO}_{2}$ control (++) are presented. Means supplying oxygen to the water aid nitrification due to its oxygen requirements (+). Packed columns and cascade aerators increase the dissolved oxygen in the water $(++)$, while at the same time stripping $\mathrm{CO}_{2}$ and nitrogen gas (++). Spray towers, used for oxygenation (++), can be modified to also strip $\mathrm{CO}_{2}$ and nitrogen gas $(++)$. Packed columns, cascade aerators and spray towers can also provide evaporation cooling in warm climates $(+)$.

Table 4. QFD matrix presenting how dissolved oxygen and $\mathrm{CO}_{2}$ control methods influence different treatment functions.

\begin{tabular}{|c|c|c|c|c|c|c|c|c|c|c|c|c|c|c|c|c|c|c|c|c|c|}
\hline $\begin{array}{l}\text { Abbreviations: } \\
\text { DO: dissolved oxygen, N: nitrogen, }\end{array}$ & Ctrl. & I. solids & Ctrl. pl & & $\begin{array}{l}\text { Ctrl. } \\
\& C\end{array}$ & $\begin{array}{cc}\mathrm{DO} \\
\mathrm{CO}_{2}\end{array}$ & & trl. N & & Ctrl. & & $\begin{array}{l}\text { Ctrl. } \\
\text { comp }\end{array}$ & & & Ctrl. & met & & & s & $\begin{array}{l}\text { Ctrl. } \\
\text { tem }\end{array}$ & \\
\hline $\begin{array}{l}\text { OM: organic matter, } \mathrm{P} \text { : phosphorus, } \\
\text { Prev: preventing, comp: compound } \\
\text { Technical solutions }\end{array}$ & $\frac{\frac{0}{0}}{\frac{0}{0}}$ & 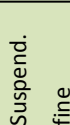 & 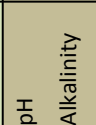 & $\begin{array}{l}\widetilde{N} \\
\stackrel{\frac{5}{0}}{\frac{0}{T}} \\
\frac{T}{I}\end{array}$ & 웅 & Оิ & 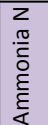 & 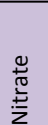 & 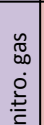 & 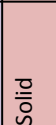 & 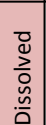 & $\frac{0}{i \frac{0}{0}}$ & 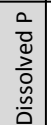 & 을 & 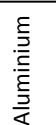 & $\stackrel{\breve{E}}{\stackrel{U}{N}}$ & $\frac{\overline{0}}{\stackrel{0}{0}}$ & 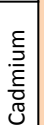 & 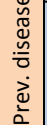 & $\begin{array}{l}\stackrel{+}{\mathbb{J}} \\
\stackrel{\overbrace{}}{I}\end{array}$ & $\overline{8}$ \\
\hline Diffusers & & & & & ++ & & + & & & & & & & & & & & & & & \\
\hline Venturi injector & & & & & ++ & & + & & & & & & & & & & & & & & \\
\hline Venturi pump & & & & & +++ & + & + & & & & & & & & & & & & & & \\
\hline Packed column & & & & & +++ & ++ & + & & ++ & & & & & & & & & & & & + \\
\hline Cascade aerator & & & & & +++ & ++ & + & & ++ & & & & & & & & & & & & + \\
\hline Spray tower - sealed & & & & & $+++t$ & ++ & + & & ++ & & & & & & & & & & & & + \\
\hline U-tubes & & & & & \begin{tabular}{|l|l}
+++ & 0 \\
++ & -1
\end{tabular} & & + & & & & & & & & & & & & & & \\
\hline Oxygenation cones & & & & & ++ & & + & & & & & & & & & & & & & & \\
\hline Counter current diffusion column & & & & & ++ & & + & & & & & & & & & & & & & & \\
\hline Low head oxygenation system (LHO) & & & & & ++ & & + & & ++ & & & & & & & & & & & & \\
\hline
\end{tabular}

Periphyton treatment (Table 5) photosynthesizes inorganic nutrients $(++)$ and carbon dioxide $(+)$ producing oxygen $(+)$ and biomass that also traps organic matter $(+)$. It also has an effect on the $\mathrm{pH}(+)$. Bio-flocs, created by flocculation of particulate organic matter $(+)$ and bacteria, utilize ammonia nitrogen $(++)$ in an aerobic process, therefore decreasing the dissolved oxygen $(-)$ and organic matter $(+)$ in the system. Bio-flocs consume alkalinity $(-)$, causing the $\mathrm{pH}$ to decrease $(-)$. In earthen ponds, ammonia nitrogen can be removed $(++)$ in various ways, such as photosynthesis, producing $\mathrm{O}_{2}(+)$, or nitrification, consuming $\mathrm{O}_{2}(-)$. In the pond, there is time for settleable solids to settle (+); phosphorus can be absorbed by the sediment in earthen ponds or retained by phytoplankton $(++)$. Long contact time between the water surface and air results in nitrogen gas removal (+). Other areas of the pond can have denitrification, as well $(++)$.

Wetlands (Table 5) remove ammonia nitrogen via plant uptake and nitrification $(++)$. They have also been found to reduce the total suspended solids (TSS) $(+)$. Occurring microorganisms in constructed wetlands can inactivate pathogenic microorganisms $(++)$ in the system given adequate retention time [17]. Bead filters use nitrification to remove ammonia nitrogen in addition to their 
solid removal function $(++)$. Nitrification however consumes oxygen $(-)$, lowers the $\mathrm{pH}(-)$ and produces $\mathrm{CO}_{2}(-)$ while oxidizing some of the dissolved organic matter $(+)$. Rotating biological contactors (RBC) and trickling filters can provide $\mathrm{O}_{2}$ addition (++) and $\mathrm{CO}_{2}$ removal (++) in addition to nitrification $(++)$. RBCs can also provide denitrification $(++)$ when used in series or submerged. With aeration, nitrogen gas is stripped (+). The trickling filter aerates the water, increases DO $(++)$, decreases $\mathrm{CO}_{2}(++)$ and nitrogen gas $(+)$, as well as provides appropriate conditions for nitrification $(++)$. Further, trickling filters can provide evaporation cooling in warm climates $(+)$. Fluidized sand filters, usually nitrification filters $(++)$, could be operated in anaerobic conditions, therefore providing denitrification (++). Downflow microbead filters can be equipped to strip $\mathrm{CO}_{2}(+)$ in addition to nitrification $(++)$. However, that is done prior to the nitrification phase, which produces $\mathrm{CO}_{2}(-)$, so net $\mathrm{CO}_{2}$ production/reduction depends on the efficiency of the nitrification and $\mathrm{CO}_{2}$ stripping. MBBRs are either operated in aerobic (nitrification) $(++)$ or anaerobic (denitrification) $(++)$ conditions.

Table 5. QFD matrix presenting how periphyton, bio-floc, earthen-ponds and wetlands influence different treatment functions.

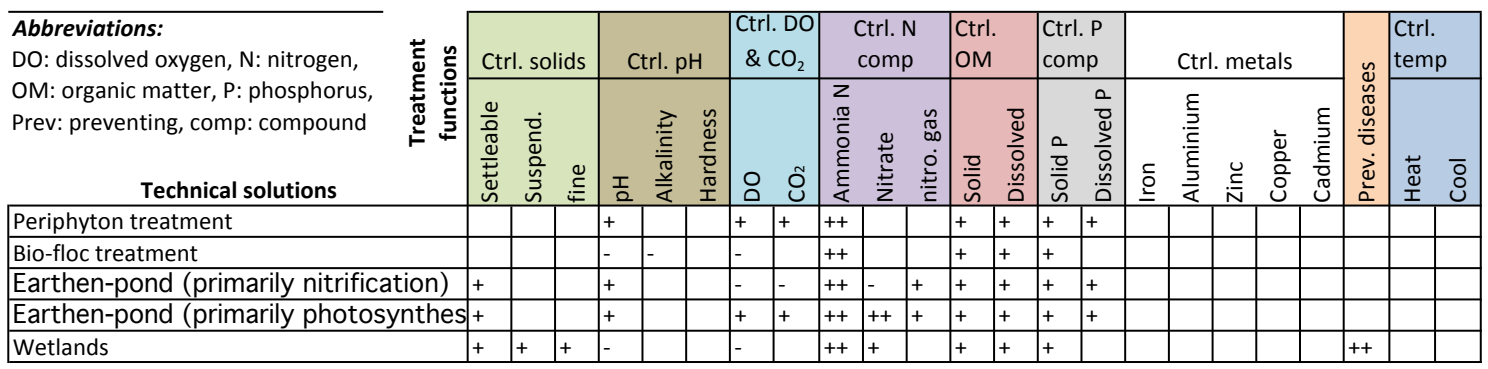

Table 6. QFD matrix presenting how biofilters influence different treatment functions.

\begin{tabular}{|c|c|c|c|c|c|c|c|c|c|c|c|c|c|c|c|c|c|c|c|c|c|c|}
\hline \multirow{2}{*}{$\begin{array}{l}\text { Abbreviations: } \\
\text { DO: dissolved oxygen, N: nitrogen, } \\
\text { OM: organic matter, P: phosphorus, } \\
\text { Prev: preventing, comp: compound } \\
\begin{array}{c}\text { Technical solutions } \\
\text { Tech }\end{array}\end{array}$} & \multicolumn{2}{|c|}{ Ctrl. solids } & \multicolumn{3}{|c|}{ Ctrl. pH } & \multicolumn{2}{|c|}{$\begin{array}{c}\text { Ctrl. DO } \\
\& \mathrm{CO}_{2} \\
\end{array}$} & \multicolumn{3}{|c|}{$\begin{array}{l}\text { Ctrl. N } \\
\text { comp }\end{array}$} & \multicolumn{2}{|c|}{$\begin{array}{l}\text { Ctrl. } \\
\text { OM }\end{array}$} & \multicolumn{2}{|c|}{$\begin{array}{l}\text { Ctrl. P } \\
\text { comp }\end{array}$} & \multicolumn{5}{|c|}{ Ctrl. metals } & \multirow[b]{2}{*}{ 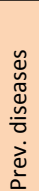 } & \multicolumn{2}{|c|}{$\begin{array}{l}\text { Ctrl. } \\
\text { temp }\end{array}$} \\
\hline & 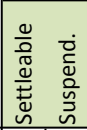 & 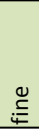 & & 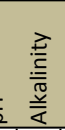 & $\begin{array}{l}\tilde{y} \\
\frac{\mathscr{c}}{0} \\
\frac{0}{\pi} \\
\frac{\pi}{I}\end{array}$ & 음 & ปิ & $\begin{array}{l}z \\
\frac{\pi}{\tau} \\
\frac{0}{\delta} \\
\xi \\
\xi \\
\end{array}$ & 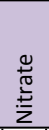 & 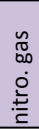 & 흥 & 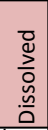 & 음 & 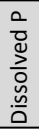 & 을 & 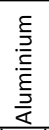 & $\stackrel{\text { U }}{\stackrel{N}{N}}$ & 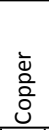 & $\frac{\varepsilon}{\bar{g}}$ & & \begin{tabular}{|l}
$\stackrel{\pi}{\pi}$ \\
$\stackrel{\pi}{I}$ \\
\end{tabular} & $\overline{8}$ \\
\hline \begin{tabular}{|l|} 
Bead filters \\
\end{tabular} & \begin{tabular}{|l|l|} 
& ++ \\
\end{tabular} & & - & & & - & - & ++ & & & ++ & + & + & & & & & & & & & \\
\hline Rotating biological contactor (RBC) & & & - & & & ++ & ++ & ++ & + & + & & + & & & & & & & & & & \\
\hline Trickling filter & & & - & & & ++ & ++ & ++ & & + & & + & & & & & & & & & & + \\
\hline Fluidized sand filter & & & - & & & - & - & ++ & ++ & & & + & & & & & & & & & & \\
\hline Down flow microbead filter w/CO2 str & & & - & & & - & + & ++ & & & & + & & & & & & & & & & \\
\hline \begin{tabular}{|l|} 
Down flow microbead filter \\
\end{tabular} & & & - & & & - & - & ++ & & & & + & & & & & & & & & & \\
\hline Moving bed bioreactor (MBBR) & & & - & & & - & - & ++ & ++ & & & + & & & & & & & & & & \\
\hline
\end{tabular}

NFT and floating raft aquaponics systems (Table 7) remove dissolved organic matter $(++)$ and nutrients, nitrate and phosphate $(++)$, from the water by plant uptake. Media bed aquaponics systems can facilitate nitrification of ammonia nitrogen $(++)$ to nitrate, which is then taken up by plants' roots $(++)$. DO reduction takes place in the hydroponics $(-)$.

Ozone, when injected into the water, oxidizes nitrite and organic matter $(++)$ and improves the flocculation of fine particles (++), making them easier to remove. This results in lower BOD and COD within the system (+). Ozone "significantly" reduces iron and copper concentration within the system and also reduces zinc (+). Reactions involving the oxidation of ammonia with ozone have been associated with an alkalinity decrease [22] (-). Ozone can also aid in the prevention of diseases, as it is an effective disinfectant of bacteria, viruses and parasites (++). UV irradiation is used in the prevention of diseases (++). In addition to destroying ozone, it is effective at destroying pathogens and other harmful organisms. Used in conjunction with ozone "practically complete disinfection" of heterotrophic bacteria can be achieved. The chemicals alum, ferric chloride and polymers flocculate 
suspended $(++)$ and fine solids $(++)$, increasing and aiding settling $(+)$, as well as flocculating dissolved phosphorus (++).

Table 7. QFD matrix presenting how aquaponic systems, adsorption, ozonation, UV irradiation and physicochemical treatment influence different treatment functions.

\begin{tabular}{|c|c|c|c|c|c|c|c|c|c|c|c|c|c|c|c|c|c|c|c|c|c|c|c|c|}
\hline \multirow{2}{*}{\multicolumn{2}{|c|}{\begin{tabular}{l} 
Abbreviations: \\
DO: dissolved oxygen, N: nitrogen, \\
OM: organic matter, P: phosphorus, \\
Prev: preventing, comp: compound \\
\multicolumn{2}{c}{ Technical solutions } \\
\end{tabular}}} & \multicolumn{3}{|c|}{ Ctrl. solids } & \multicolumn{3}{|c|}{ Ctrl. pH } & \multicolumn{2}{|c|}{$\begin{array}{c}\text { Ctrl. DO } \\
\& \mathrm{CO}_{2}\end{array}$} & \multicolumn{3}{|c|}{$\begin{array}{l}\text { Ctrl. N } \\
\text { comp }\end{array}$} & \multicolumn{2}{|c|}{$\begin{array}{l}\text { Ctrl. } \\
\text { OM }\end{array}$} & \multicolumn{2}{|c|}{$\begin{array}{l}\text { Ctrl. P } \\
\text { comp }\end{array}$} & \multicolumn{5}{|c|}{ Ctrl. metals } & \multirow[b]{2}{*}{ 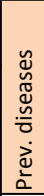 } & \multicolumn{2}{|c|}{$\begin{array}{l}\text { Ctrl. } \\
\text { temp }\end{array}$} \\
\hline & & 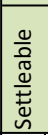 & 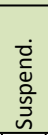 & $\underset{4}{ \pm}$ & 동 & 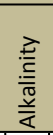 & 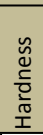 & 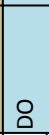 & ญิ & 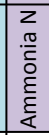 & 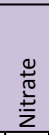 & 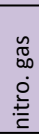 & 음 & 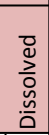 & $\begin{array}{l}0 \\
\frac{0}{0} \\
\text { ○ } \\
\text { 乞 }\end{array}$ & 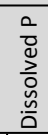 & 돈 & 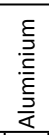 & $\underset{N}{\stackrel{U}{N}}$ & $\begin{array}{l}\bar{\Xi} \\
\text { 응 }\end{array}$ & $\begin{array}{l}\frac{\varepsilon}{J} \\
\frac{\bar{g}}{0} \\
\tilde{J} \\
\end{array}$ & & 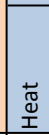 & $\overline{8}$ \\
\hline Floating raft and NFT aquaponic syste & & & & & + & & & - & & & ++ & & & ++ & & ++ & & & & & & & & \\
\hline Media bed aquaponic system & & & & & + & & & - & - & ++ & ++ & & & ++ & ++ & ++ & & & & & & & & \\
\hline Adsorption & & & & & & & & & & & & & & ++ & & & & & & & & & & \\
\hline Ozone addition & & & & ++ & & - & & + & & + & & & ++ & ++ & & & ++ & & ++ & ++ & & ++ & & \\
\hline UV irradiation & & & & + & & & & & & & & & + & + & & & & & & & & ++ & & \\
\hline Physiochemical treatment (Alur & $n, \ldots)$ & + & ++ & ++ & & & & & & & & & ++ & & ++ & ++ & & & & & & & & \\
\hline
\end{tabular}

Disinfecting equipment (Table 8) prevents diseases (++) and controls disease outbreaks (++) (maintain hygiene). Different techniques/chemicals are used for disinfecting equipment, which have different costs, handling (procedures) difficulties, etc. These methods are not considered to have any other beneficial $(+)$ or negative $(-)$ effect on other treatment functions.

Although practical applications were not found, exposing fish to electromagnetic waves can improve their disease resistance $(++)$.

Technical solutions to controlling the temperature of the culture water do not influence other treatment functions. Immersion heaters and oil and gas burners provide heat $(++)$, while heat exchangers and heat pumps can be used to either heat or cool the culture water $(++)$. Often in aquaculture, a combination of those technical solutions (heaters, heat exchangers and heat pumps) is used to control the temperature of the culture water. Direct mixing of water or seawater $(++)$ should not be mistaken as a water exchange. This water/seawater can originate from a different source than the inlet water, such as storage tanks, colder streams or wells, and different depths in seawater. This mixing can either be continuous or added discontinuously as needed.

Table 8. QFD matrix presenting how technical solutions for preventing diseases and controlling temperature influence different treatment functions.

\begin{tabular}{|c|c|c|c|c|c|c|c|c|c|c|c|c|c|c|c|c|c|c|c|c|c|c|}
\hline $\begin{array}{l}\text { Abbreviations: } \\
\text { DO: dissolved oxygen, } \mathrm{N} \text { : nitrogen, }\end{array}$ & Ctrl & I. solids & & Ctrl. pl & & $\begin{aligned} \text { Ctrl. } \\
\& C\end{aligned}$ & & & $\begin{array}{l}\text { Ctrl. N } \\
\text { comp }\end{array}$ & & Ctrl. & & $\begin{array}{l}\text { Ctrl. } \\
\text { com }\end{array}$ & & & Ctrl. $r$ & meta & & & 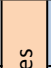 & $\begin{array}{l}\text { Ctrl. } \\
\text { tem }\end{array}$ & \\
\hline $\begin{array}{l}\text { OM: organic matter, P: phosphorus, } \\
\text { Prev: preventing, comp: compound } \\
\text { Technical solutions }\end{array}$ & 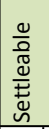 & 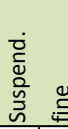 & $\stackrel{巳}{\rightleftarrows}$ & 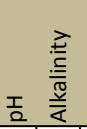 & $\begin{array}{l}\tilde{y} \\
\frac{\tilde{y}}{0} \\
\frac{1}{1} \\
\frac{1}{1}\end{array}$ & & Оิ & 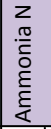 & 荧 & 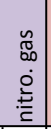 & $\frac{0}{\overline{0}}$ & 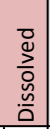 & $\frac{0}{0}$ & 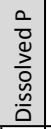 & 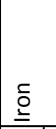 & 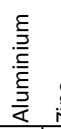 & $\stackrel{U}{\stackrel{U}{N}}$ & ¿্̀ & \begin{tabular}{l|}
$\frac{\xi}{\partial}$ \\
$\frac{\varepsilon}{\varepsilon}$ \\
$\frac{0}{U}$ \\
\end{tabular} & 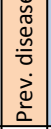 & \begin{tabular}{|l}
$\stackrel{\pi}{\pi}$ \\
$\stackrel{1}{T}$ \\
\end{tabular} & $\overline{0}$ \\
\hline Disinfection of equipment & & & & & & & & & & & & & & & & & & & & ++ & & \\
\hline Electromagnets & & & & & & & & & & & & & & & & & & & & ++ & & \\
\hline Vaccination (Injection, osmotic, oral,...) & & & & & & & & & & & & & & & & & & & & ++ & & \\
\hline Immersion heaters & & & & & & & & & & & & & & & & & & & & & ++ & \\
\hline Oil and gas burners & & & & & & & & & & & & & & & & & & & & & ++ & \\
\hline Heat exchangers & & & & & & & & & & & & & & & & & & & & & ++ & ++ \\
\hline Heat pumps & & & & & & & & & & & & & & & & & & & & & ++ & ++ \\
\hline Ice addition & & & & & & & & & & & & & & & & & & & & & & ++ \\
\hline Direct mixing of water or seawater & & & & & & & & & & & & & & & & & & & & & ++ & ++ \\
\hline
\end{tabular}

\section{Discussion}

This series of articles has only been a waypoint on a greater journey. To map out the aquaculture production system as a transformation process, describe all of the ways each function can be solved and trying to create an overview of the interaction was not the final objective. What we do want to achieve is a complete aquaculture engineering design methodology. To do that, several things remain to be done. 
Future work could include several directions, like the taxonomy of input and output functions and their technological solutions, further work with quality function deployment, better evaluation of the interactions (quantification) and last, but not the least, the next step in the aquaculture engineering design methodology. Let us look at those in turn.

The taxonomy presented in these four parts did not include input and output functions. It would be beneficial to map out all of the technical solutions to those functions in a similar manner as we have done here. That would complete the taxonomy. Using the QFD methodology to describe how the customer needs can be linked to the aquaculture production design would have great benefits. Such an approach could take into account a green-field design of a production system, an upgrade approach (intensification) and selection strategies for technical solutions. At the other end, finding how the performance indicators deal or link with each technical solution would further the work towards a design methodology. Here, we have only coarsely evaluated the strength of the interaction between treatment functions and technical solutions. A second round would be appropriate to increase the granularity of the link, a better quantification of the link than the current main function (++), derived benefit $(+)$ and negative effect $(-)$. This syntax does not allow us to choose between different technical solutions of from the same group, e.g., how effective are the different screen filters as listed in Table 1 A quantification scheme, e.g., a scale of one to five or similar, on each link would facilitate the making of design strategies. Finally, tying all of those things into a complete aquaculture engineering design methodology would be the final grand step.

Supplementary Materials: A complete QFD matrix is available online at www.mdpi.com/2073-4441/8/11/487/s1.

Author Contributions: Gudmundur V. Oddsson and Bjorgvin Vilbergsson conceived of and designed the work. Bjorgvin Vilbergsson performed the systematic literature review. Bjorgvin Vilbergsson analyzed the data. Gudmundur V. Oddsson and Runar Unnthorsson structured the paper and reviewed the results. All authors wrote the paper.

Conflicts of Interest: The authors declare no conflict of interest.

\section{References}

1. Martins, C.; Eding, E.; Verdegem, M.; Heinsbroek, L.; Schneider, O.; Blancheton, J.; D'Orbcastel, E.R.; Verreth, J. New developments in recirculating aquaculture systems in Europe: A perspective on environmental sustainability. Aquac. Eng. 2010, 43, 83-93.

2. Badiola, M.; Mendiola, D.; Bostock, J. Recirculating Aquaculture Systems (RAS) analysis: Main issues on management and future challenges. Aquac. Eng. 2012, 51, 26-35.

3. Björnsdóttir, R.; Oddsson, G.V.; Thorarinsdottir, R.; Unnthorsson, R. Taxonomy of means and ends in aquaculture production-Part 1: The functions. Water 2016, 8, 319.

4. Vilbergsson, B.; Oddsson, G.V.; Unnthorsson, R. Taxonomy of means and ends in aquaculture production—Part 2: The technical solutions of controlling solids, disolved gasses and $\mathrm{pH}$. Water 2016, 8, 387.

5. Vilbergsson, B.; Oddsson, G.V.; Unnthorsson, R. Taxonomy of means and ends in aquaculture production-Part 3: The technical solutions of controlling $\mathrm{N}$ compounds, organic matter, P compounds, metals, temperature and preventing disease. Water 2016, 8, 319.

6. Bahill, A.T.; Chapman, W.L. A Tutorial on Quality Function Deployment. Eng. Manag. J. 1993, 5, $24-35$.

7. Liltved, H.; Cripps, S. Removal of particle-associated bacteria by prefiltration and ultraviolet irradiation. Aquac. Res. 1999, 30, 445-450.

8. Summerfelt, R.C.; Penne, C.R. Solids removal in a recirculating aquaculture system where the majority of flow bypasses the microscreen filter. Aquac. Eng. 2005, 33, 214-224.

9. Ebeling, J.; Welsh, C.; Rishel, K. Performance evaluation of an inclined belt filter using coagulation/flocculation aids for the removal of suspended solids and phosphorus from microscreen. Aquac. Eng. 2006, 35, 61-77.

10. Holan, A.; Wold, P.A.; Leiknes, T. Intensive rearing of cod larvae (Gadus morhua) in recirculating aquaculture systems (RAS) implementing a membrane bioreactor (MBR) for enhanced colloidal particle and fine suspended solids removal. Aquac. Eng. 2014, 58, 52-58.

11. Cripps, S.J.; Bergheim, A. Solids management and removal for intensive land-based aquaculture production systems. Aquac. Eng. 2000, 22, 33-56. 
12. Tidwell, J. Aquaculture Production Systems; Wiley-Blackwell: Oxford, UK, 2012.

13. Loyless, J.; Malone, R. A sodium bicarbonate dosing methodology for $\mathrm{pH}$ management in freshwater-recirculating aquaculture systems. Prog. Fish Cult. 1997, 59, 198-205.

14. Boyd, C.; Tucker, C.; Viriyatum, R. Interpretation of $\mathrm{pH}$, acidity, and alkalinity in aquaculture and fisheries. N. Am. J. Aquac. 2011, 73, 403-408.

15. Timmons, M.B.; Ebeling, J.M. Recirculating Aquaculture, 2nd ed.; Cayuga Aqua Ventures: Ithaca, NY, USA, 2010.

16. Rosseland, B.O.; Skogheim, O.K. Neutralization of acidic brook-water using a shell-sand filter or sea-water: Effects on eggs, alevins and smolts of salmonids. Aquaculture 1986, 58, 99-110.

17. Lekang, O. Aquaculture Engineering; Blackwell Publishing Ltd.: Oxford, UK, 2007.

18. Teien, H.C.; Kroglund, F.; Atland, A.; Rosseland, B.O.; Salbu, B. Sodium silicate as alternative to liming-reduced aluminum toxicity for Atlantic salmon (Salmo salar L.) in unstable mixing zones. Sci. Total Environ. 2006, 358, 151-163.

19. Furtado, P.S.; Gaona, C.A.P.; Poersch, L.H.; Wasielesky, W. Application of different doses of calcium hydroxide in the farming shrimp Litopenaeus vannamei with the biofloc technology (BFT). Aquac. Int. 2013, 22, 1009-1023.

20. Sharrer, M.J.; Rishel, K.; Summerfelt, S. Evaluation of geotextile filtration applying coagulant and flocculant amendments for aquaculture biosolids dewatering and phosphorus removal. Aquac. Eng. 2009, 40, 1-10.

21. Boyd, C.E.; Tucker, C.S.; Somridhivej, B. Alkalinity and Hardness: Critical but Elusive Concepts in Aquaculture. J. World Aquac. Soc. 2016, 47, 6-41.

22. Whangchai, N.; Migo, V.P.; Alfafara, C.G.; Young, H.K.; Nomura, N.; Matsumura, M. Strategies for alkalinity and $\mathrm{pH}$ control for ozonated shrimp pond water. Aquac. Eng. 2004, 30, 1-13.

23. Das, B.K.; Das, N. Impacts of quicklime $(\mathrm{CaO})$ on the toxicity of copper $(\mathrm{CuSO} 4,5 \mathrm{H} 2 \mathrm{O})$ to fish and fish food organisms. Chemosphere 2005, 61, 186-191.

24. Kaviraj, A.; Dutta, T.K. Use of Quick Lime (CaO) as a Means to Reduce Cadmium Toxicity in Common Carp, Cyprinus carpio. J. Appl. Aquac. 2008, 10, 87-95.

25. Colt, J. Water quality requirements for reuse systems. Aquac. Eng. 2006, 34, 143-156.

26. Hackney, G.E.; Colt, J.E. The performance and design of packed column aeration systems for aquaculture. Aquac. Eng. 1982, 1, 275-295.

27. Watten, B.J.; Sibrell, P.L.; Montgomery, G.A.; Tsukuda, S.M. Modification of pure oxygen absorption equipment for concurrent stripping of carbon dioxide. Aquac. Eng. 2004, 32, 183-208.

28. Loyless, J.; Malone, R.F. Evaluation of air-lift pump capabilities for water delivery, aeration, and degasification for application to recirculating aquaculture systems. Aquac. Eng. 1998, 18, 117-133.

29. Barrut, B.; Blancheton, J.P.; Champagne, J.Y.; Grasmick, A. Mass transfer efficiency of a vacuum airlift-Application to water recycling in aquaculture systems. Aquac. Eng. 2012, 46, 18-26.

30. Seginer, I.; Mozes, N. A note on oxygen supply in RAS: The effect of water temperature. Aquac. Eng. 2012, 50, 46-54.

31. Summerfelt, S.; Vinci, B.; Piedrahita, R. Oxygenation and carbon dioxide control in water reuse systems. Aquac. Eng. 2000, 22, 87-108.

32. Losordo, T.; Masser, M.; Rakocy, J. Recirculating Aquaculture Tank Production Systems-A Review of Component Options; SRAC Publication: Stoneville, MS, USA, 1999.

33. Timmons, M.B.; Holder, J.L.; Ebeling, J.M. Application of microbead biological filters. Aquac. Eng. 2006, 34, 332-343.

34. Brazil, B.L. Performance and operation of a rotating biological contactor in a tilapia recirculating aquaculture system. Aquac. Eng. 2006, 34, 261-274.

35. Crab, R.; Avnimelech, Y.; Defoirdt, T.; Bossier, P.; Verstraete, W. Nitrogen removal techniques in aquaculture for a sustainable production. Aquaculture 2007, 270, 1-14.

36. Hamlin, H.; Michaels, J.; Beaulaton, C.; Graham, W.; Dutt, W.; Steinbach, P.; Losordo, T.; Schrader, K.; Main, K. Comparing denitrification rates and carbon sources in commercial scale upflow denitrification biological filters in aquaculture. Aquac. Eng. 2008, 38, 79-92.

37. Davidson, J.; Good, C.; Welsh, C.; Summerfelt, S. The effects of ozone and water exchange rates on water quality and rainbow trout Oncorhynchus mykiss performance in replicated water recirculating systems. Aquac. Eng. 2011, 44, 80-96. 
38. Summerfelt, S.T.; Sharrer, M.J. Design implication of carbon dioxide production within biofilters contained in recirculating salmonid culture systems. Aquac. Eng. 2004, 32, 171-182.

39. Beveridge, M.; Beveridge, M.; Verdegem, M.; Van Dam, A.A.; Azim, M.E. The potential of fish production based on periphyton. Rev. Fish Biol. Fish. 2002, 12, 1-31.

40. Azim, M.; Little, D. The biofloc technology (BFT) in indoor tanks: Water quality, biofloc composition, and growth and welfare of Nile tilapia (Oreochromis niloticus). Aquaculture 2008, 283, 29-35.

41. Silva, K. Nitrogen and phosphorus dynamics in the biofloc production of the pacific white shrimp, Litopenaeus vannamei. J. World Aquac. Soc. 2013, 44, 30-41.

42. Gál, D.; Pekár, F.; Kerepeczki, É.; Váradi, L. Experiments on the operation of a combined aquaculture-algae system. Aquac. Int. 2007, 15, 173-180.

43. Hargreaves, J.A. Photosynthetic suspended-growth systems in aquaculture. Aquac. Eng. 2006, 34, $344-363$.

44. Lin, Y.F.; Jing, S.R.; Lee, D.Y. The potential use of constructed wetlands in a recirculating aquaculture system for shrimp culture. Environ. Pollut. 2003, 123, 107-113.

45. Kadlec, R.; Wallace, S. Treatment Wetlands, 2nd ed.; Taylor \& Francis Group: New York, NY, USA, 2009.

46. Ayoub, G.M.; Saikaly, P. The combined effect of step-feed and recycling on RBC performance. Water Res. 2004, 38, 3009-3016.

47. Cortez, S.; Teixeira, P.; Oliveira, R.; Mota, M. Rotating biological contactors: A review on main factors affecting performance. Rev. Environ. Sci. Biotechnol. 2008, 7, 155-172.

48. Eding, E.; Kamstra, A.; Verreth, J.; Huisman, E.; Klapwijk, A. Design and operation of nitrifying trickling filters in recirculating aquaculture: A review. Aquac. Eng. 2006, 34, 234-260.

49. Malone, R.F.; Beecher, L.E. Use of floating bead filters to recondition recirculating waters in warmwater aquaculture production systems. Aquac. Eng. 2000, 22, 57-73.

50. Tsukuda, S.; Christianson, L.; Kolb, A.; Saito, K.; Summerfelt, S. Heterotrophic denitrification of aquaculture effluent using fluidized sand biofilters. Aquac. Eng. 2015, 64, 49-59.

51. Rusten, B.; Eikebrokk, B.; Ulgenes, Y.; Lygren, E. Design and operations of the Kaldnes moving bed biofilm reactors. Aquac. Eng. 2006, 34, 322-331.

52. Lennard, W.A.; Leonard, B.V. A Comparison of Three Different Hydroponic Sub-systems (gravel bed, floating and nutrient film technique) in an Aquaponic Test System. Aquac. Int. 2006, 14, 539-550.

53. Endut, A.; Jusoh, A.; Ali, N.; Wan Nik, W.B.; Hassan, A. A study on the optimal hydraulic loading rate and plant ratios in recirculation aquaponic system. Bioresour. Technol. 2010, 101, 1511-1517.

54. Barrut, B.; Blancheton, J.P.; Callier, M.; Champagne, J.Y.; Grasmick, A. Foam fractionation efficiency of a vacuum airlift-Application to particulate matter removal in recirculating systems. Aquac. Eng. 2013, 54, $16-21$.

55. Gutierrez-Wing, M.T.; Malone, R.F. Biological filters in aquaculture: Trends and research directions for freshwater and marine applications. Aquac. Eng. 2006, 34, 163-171.

56. Lam, S.S.; Ma, N.L.; Jusoh, A.; Ambak, M.A. Biological nutrient removal by recirculating aquaponic system: Optimization of the dimension ratio between the hydroponic \& rearing tank components. Int. Biodeterior. Biodegrad. 2015, 102, 107-115.

57. Aitcheson, S.; Arnett, J.; Murray, K.; Zhang, J. Removal of aquaculture therapeutants by carbon adsorption. Aquaculture 2000, 183, 269-284.

58. Schroeder, J.; Croot, P.; Von Dewitz, B.; Waller, U.; Hanel, R. Potential and limitations of ozone for the removal of ammonia, nitrite, and yellow substances in marine recirculating aquaculture systems. Aquac. Eng. 2011, 45, 35-41.

59. Summerfelt, S.T.; Sharrer, M.J.; Hollis, J.; Gleason, L.E.; Summerfelt, S.R. Dissolved ozone destruction using ultraviolet irradiation in a recirculating salmonid culture system. Aquac. Eng. 2004, 32, 209-223.

60. True, B.; Johnson, W.; Chen, S. Reducing phosphorus discharge from flow-through aquaculture I: Facility and effluent characterization. Aquac. Eng. 2004, 32, 129-144.

61. Masser, M.; Rakocy, J.; Losordo, T. Recirculating Aquaculture Tank Production Systems-Management of Recirculating Systems; SRAC Publication: Stoneville, MS, USA, 1999.

62. Bullock, G.L.; Summerfelt, S.T.; Noble, A.C.; Weber, A.L.; Durant, M.D.; Hankins, J.A. Ozonation of a recirculating rainbow trout culture system $\mathrm{I}$. Effects on bacterial gill disease and heterotrophic bacteria. Aquaculture 1997, 158, 43-55. 
63. Mamane, H.; Colorni, A.; Bar, I.; Ori, I.; Mozes, N. The use of an open channel, low pressure UV reactor for water treatment in low head recirculating aquaculture systems (LH-RAS). Aquac. Eng. 2010, 42, 103-111.

64. Summerfelt, S.T.; Sharrer, M.J.; Tsukuda, S.M.; Gearheart, M. Process requirements for achieving full-flow disinfection of recirculating water using ozonation and UV irradiation. Aquac. Eng. 2009, 40, 17-27.

65. Nofouzi, K.; Sheikhzadeh, N.; Mohamad-Zadeh Jassur, D.; Ashrafi-Helan, J. Influence of extremely low frequency electromagnetic fields on growth performance, innate immune response, biochemical parameters and disease resistance in rainbow trout, Oncorhynchus mykiss. Fish Physiol. Biochem. 2015, 41, 721-731.

66. Stickney, R.R. Aquaculture: An Introductory Text; CAB International: Cambridge, MA, USA, 2005.

(C) 2016 by the authors; licensee MDPI, Basel, Switzerland. This article is an open access article distributed under the terms and conditions of the Creative Commons Attribution (CC-BY) license (http://creativecommons.org/licenses/by/4.0/). 